\title{
The Sustainable Strategy Of PT. Indofood CBP Sukses Makmur In Facing The Era Of Economic Disruption
}

Due to advances in information technology, companies are required to make changes to business concepts in the industrial era 4.0. (Tayibnapis, E. Wuryaningsih and Gora, 2019). Companies in Indonesia are required to always generate new values in all aspects so that performance can improve and be good for the company, and are able to survive in the market by obtaining positive benefits. (Tayibnapis, E. Wuryaningsih and Gora, 2019). In dealing with change, each company responds in different ways, one of which is done by PT. Indofood Sukses Makmur Tbk. :

1. GCG is essentially a set of rules that regulate, manage, and supervise the relationship between company managers and stakeholders in the company in an effort to increase company value and market valuation. (Tayibnapis, E. Wuryaningsih and Gora, 2019). In implementing sustainable competitiveness, the implementation of Good Corporate Governance (GCG) by PT. Indofood Sukses Makmur Tbk:

Learning process: a transfer of knowledge not only from Indofood subsidiaries, but also from established companies as well as from a diversity of research and development teams to become a learning strategy stage for Indofood.

Deverage process: Indofood analyze the opportunities and challenges of the company through the G-5 strategy to expand overseas markets with the right strategy, analysis and keeping abreast of market developments is carried out by acquisitions, alliances, joint ventures, to get superior products

2. Innovation : Competitive advantage has become a necessity for every company in the face of economic difficulties. When a company wants to survive in the domestic and global markets, one of the things that must be done by PT Indofood CBP Sukses Makmur Tbk is continuous innovation. Although company has succeeded in almost all of its products, PT 
Indofood CBP Sukses Makmur Tbk continues to develop innovations in its products. In fact, Indofood CBP is now innovating its instant noodle products starting from the appearance of packaging and increasingly diverse flavors. This was done by company to continue to attract consumer interest and make Indomie into a product that has advantages in various ways which currently has many competitors. Not only indomie, Indofood also produces various kinds of snacks, which are widely sold in the market. To survive in the market, PT. Indofood CBP Sukses Makmur makes a variety of packaging sizes and various flavors in its products. For example Indofood also produces its newest product, Qtela Opak. The launch of this new variant also strengthens Qtela's position as a market leader in the modern snack category with a traditional concept that continues to innovate. And to continue to survive in the market now Indofood annually innovates its newest products so that it has a wide variety of the latest products.

3. Human Resources : To achieve sustainable competitiveness, a system of good corporate governance mechanisms can create added value for all stakeholders. (Tayibnapis, E. Wuryaningsih and Gora, 2019). A clear framework so that the direction of the organization becomes clear and measurable, and the implementation of a strategy to build the organization's HR capabilities is very important. Recognizing the important role of human resources in supporting the success and sustainability of PT Indofood Tbk. The company places human resource management as one of the main strategies and keys to successful performance. (Tayibnapis, E. Wuryaningsih and Gora, 2019). Until now, PT Indofood has employed tens of thousands of employees with different democratic conditions and competencies. Not infrequently the development process is also followed by the provision of new training facilities and training modules tailored to the needs. The amount of attention given by Indofood companies to its human resources is shown by providing training based on competency needs in each position, starting from the operational level which is technical to higher levels and is managerial and leadership competence. This seriousness is in line with the company's mission :

$\checkmark$ Provide solutions to food needs in a sustainable manner

$\checkmark$ Constantly improving employee competencies, production levels and technology 
$\checkmark$ Contribute to the welfare of society and the environment in a sustainable manner

$\checkmark$ Increase stakeholders' values on an ongoing basis.

PT Indofood continues to strive to foster good relationships with employees at all levels of staff to management for mutual benefit and in maintaining market share and increasingly competitive market advantages. This strategy is implemented as an effort to improve or increase the company's commitment to consumer trust, where each employee acts as a subject that supports the company in quality improvement and innovation.

4. Low cost leadership strategy : Indofood manufactures its products. A low cost strategy does not imply low value or quality of goods. One of the triggers for a low cost strategy is the facilities that are utilized effectively, reliable human resources, and competent leaders. Indofood. using a low cost strategy understands this and utilizes its resources effectively. By identifying the optimal size, Indofood can spread costs across units to lower costs and make them superior. In addition, Indofood products always pay attention to the quality and quantity aspects of its products. ISM products are of high quality in terms of taste, packing etc. 


\section{DAFTAR PUSTAKA}

Tayibnapis, A. Z., E. Wuryaningsih, L. and Gora, R. (2019) 'Companies in Indonesia in the vortex of global economic disruption', 308(Insyma), pp. 174-177. doi: 10.2991/insyma-19.2019.45.

Tayibnapis, A. Z., E. Wuryaningsih, L. and Gora, R. (2019) 'Companies in Indonesia in the vortex of global economic disruption', 308(Insyma), pp. 174-177. doi: 10.2991/insyma-19.2019.45.

Tayibnapis, A. Z., E. Wuryaningsih, L. and Gora, R. (2019) 'Companies in Indonesia in the vortex of global economic disruption', 308(Insyma), pp. 174-177. doi: 10.2991/insyma-19.2019.45.

Tayibnapis, A. Z., E. Wuryaningsih, L. and Gora, R. (2019) 'Companies in Indonesia in the vortex of global economic disruption', 308(Insyma), pp. 174-177. doi: 10.2991/insyma-19.2019.45.

Tayibnapis, A. Z., E. Wuryaningsih, L. and Gora, R. (2019) 'Companies in Indonesia in the vortex of global economic disruption', 308(Insyma), pp. 174-177. doi: 10.2991/insyma-19.2019.45. 